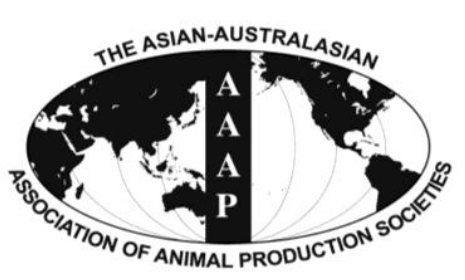

Open Access

Asian Australas. J. Anim. Sci.

Vol. 27, No. 3 : 383-390 March 2014

http://dx.doi.org/10.5713/ajas.2013.13485

www.ajas.info

pISSN 1011-2367 elSSN 1976-5517

\title{
Effects of Dietary Supplementation of Barodon, an Anionic Alkali Mineral Complex, on Growth Performance, Feed Utilization, Innate Immunity, Goblet Cell and Digestibility in Olive Flounder (Paralichthys olivaceus)
}

\author{
Chang-Hoon Shin ${ }^{1}$, Ji-Hoon Cha ${ }^{2}$, Samad Rahimnejad ${ }^{2}$, Joon-Bum Jeong ${ }^{3}$, Byung-Woo Yoo ${ }^{4}$, Bo-Kyeun Lee ${ }^{4}$, \\ Hyung-Jin $\mathrm{Ahn}^{4}$, Soo-Il Choi ${ }^{5}$, Yun-Jeong Choi ${ }^{5}$, Yong-Ho Park ${ }^{6}$, Jeong-Dae Kim ${ }^{1}$, and Kyeong-Jun Lee, ${ }^{2,7 *}$ \\ ${ }^{1}$ Department of Animal Life system, Kangwon National University, Chuncheon 200-701, Korea
}

\begin{abstract}
A 15-wk feeding trial was conducted to examine the supplemental effects of Barodon on growth performance, gastrointestinal histology, feed digestibility and innate immunity in olive founder. A basal commercial diet was used as a control and two other diets were prepared by spraying $0.1 \%$ or $0.2 \%$ of Barodon. Triplicate groups of fish (BW, $145 \mathrm{~g}$ ) were fed one of the test diets to apparent satiation twice daily. At the end of the feeding trial, fish growth performance was not significantly affected by dietary treatments; however, feed utilization was significantly improved (linear and quadratic, $\mathrm{p}<0.05$ ) by Barodon supplementation. Significantly higher $(\mathrm{p}<0.05)$ survival rates were obtained in fish fed Barodon containing diets. Hepatosomatic index increased significantly in Barodon treated groups. Also, the use of Barodon resulted in significant increase (linear and quadratic, $\mathrm{p}<0.05$ ) of intestine length and number of goblet cells. Significantly higher (Quadratic, p<0.05) apparent digestibility coefficient of DM was obtained by supplementation of Barodon. Lysozyme and myeloperoxidase activities increased quadratically and linearly, respectively, in Barodon treated fish. Also, significantly higher (linear and quadratic, $p<0.05$ ) superoxide dismutase activity was found in Barodon fed fish. The findings in this study show that inclusion of Barodon in diets for olive flounder improves feed utilization and digestibility, and positively affects digestive tract histology and innate immunity. (Key Words: Olive Flounder, Barodon, Growth, Gastrointestinal Histology, Nutrient Digestibility, Innate Immunity)
\end{abstract}

\section{INTRODUCTION}

Aquaculture remains one of the fastest-growing animal

\footnotetext{
* Corresponding Author: Kyeong-Jun Lee. Tel: +82-64-754-3423, Fax: +82-64-756-3493, E-mail: kjlee@ jejunu.ac.kr

${ }^{2}$ Department of Marine Life Sciences, Jeju National University, Jeju 690-756, Korea.

3 Department of Aquatic Biomedical Science, Jeju National University, Jeju 690-756, Korea.

${ }^{4}$ Cargill Agri Purina Inc, Seongnam, Gyeonggi, Korea.

${ }^{5}$ Barodon - S.F. Corp, Ansung, Gyeonggi, Korea.

${ }^{6}$ College of Veterinary Medicine, Seoul National University, Seoul, Korea.

7 Marine \& Environmental Research Institute, Jeju National University, Jeju 695-814, Korea.

Submitted Aug. 8, 2013; Accepted Oct. 20, 2013; Revised Dec. 2, 2013
}

food-producing sectors accounting for almost half of the total food fish production (FAO, 2010). Aquaculture has expanded during the past several decades, and this industry has a high density stocking strategy due to the pursuit of maximum productivity in limited culture systems. Intensive aquaculture triggers higher susceptibility to disease and significant losses in aquaculture. Protection of farmed fish from various diseases is a prerequisite for increasing production and further development of aquaculture. A wide range of antimicrobial compounds have been used for treatment of infectious bacterial diseases in aquaculture farms (Carnevail et al., 2004; Lauzon et al., 2010). Antibiotics have several harmful side effects, such as development of antibiotic resistant strains of pathogens and concerns regarding the antibiotic residues in the environment and food safety (Kumari and Sahoo, 2006; 
Sahu et al., 2007). Therefore, a prerequisite for aquaculture to prosper in the future is to minimize the use of antibiotics in controlling fish disease (Wu et al., 2007).

Prevention of fish disease through stimulation of the immune system is considered as a promising approach for sustainable aquaculture (Ardo et al., 2008). Immunostimulants enhance the overall resistance against pathogens by stimulation of the non-specific immune response (Sakai, 1999; Gannam and Schrock, 2001) which plays a key role in immunity during the initial stages of infection (Divyagnaneswari et al., 2007; Swain et al., 2007).

Several immunostimulants have been examined in fish and shrimp including both synthetic chemicals and natural biological substances (Sakai, 1999). Barodon, an anionic alkali mineral complex, has been identified as a potential immunstimulant in terrestrial animals, such as pigs and horses. It is composed of an alkali solution ( $\mathrm{pH}$ 13.5) containing $\mathrm{Si}, \mathrm{Ag}$ and $\mathrm{K}$ ions. Its immunomodulatory activity has been demonstrated by proliferation and activation of porcine immune cells, particularly $\mathrm{CD} 4^{+} \mathrm{CD} 8^{+}$ double-positive $\mathrm{T}$ lymphocytes in peripheral blood and in the secondary lymphoid organ (Yoo et al., 2001, 2002). Also, it was shown to have an adjuvant effect on hog cholera vaccine efficiency (Park et al., 2000). However, to the best of our knowledge there is no available information on its beneficial effects in fish.

Olive flounder is one of the most important fish species for marine aquaculture in Asian countries, and has been successfully cultured in Korea, Japan and China (Kang et al., 2008; Castaño-Sánchez et al., 2010). Regarding the commercial importance of this species in Korea, a feeding trial was undertaken to examine the supplemental effects of Barodon on growth performance, feed utilization, nonspecific immune response, gastrointestinal histology and feed digestibility.

\section{MATERIALS AND METHODS}

\section{Experimental diets}

A basal commercial diet (Cargill Agri Purina Co., South Korea) with $55 \%$ crude protein and $7 \%$ crude lipid was used as a control and two other diets were prepared by supplementation of $0.1 \%$ or $0.2 \%$ Barodon (Barodon-S.F, Korea). Composition of Barodon used in this study is shown in Table 1. The targeting concentrations of Barodon were sprayed to the basal diet after dilution in distilled water ( $2 \%$ of diet wt). The control diet was treated similarly but no Barodon was included. The diets were dried at room temperature using electric fans and stored at $-20^{\circ} \mathrm{C}$ until use.

\section{Feeding trial and sample collection}

Growing olive flounders were transported from a
Table 1. Composition of major ingredients for Barodon

\begin{tabular}{lc}
\hline Ingredient & Amount \\
\hline $\mathrm{Na}_{2} \mathrm{SiO}_{3}(\mathrm{~g})$ & 600 \\
$\mathrm{~K}_{2} \mathrm{CO}_{3}(\mathrm{~g})$ & 300 \\
$\mathrm{Na}_{2} \mathrm{CO}_{3}(\mathrm{~g})$ & 9 \\
$\mathrm{Na}_{2} \mathrm{~B}_{4} \mathrm{O}_{7}(\mathrm{~g})$ & 9 \\
$\mathrm{C}_{12} \mathrm{H}_{22} \mathrm{O}_{11}$ & q.s. \\
$\mathrm{AgNO}_{3}$ & q.s. \\
$\mathrm{NaCl}$ & q.s. \\
$\mathrm{Na}_{2} \mathrm{~S}_{2} \mathrm{O}_{3}(\mathrm{~g})$ & 0.12 \\
$\mathrm{H}_{2} \mathrm{O}(\mathrm{mL})$ & 1,000
\end{tabular}

${ }^{1}$ q.s $=$ Quantum satis.

private hatchery (Dong-won Fisheries, Jeju Island, Korea) to Marine and Environmental Research Institute, Jeju National University (Jeju, Korea). All fish were acclimated to the experimental conditions and facilities for $2 \mathrm{wk}$. At the end of the acclimation period, twenty fish averaging at 145 $\mathrm{g}$ were stocked in each polyvinyl circular tanks of $400 \mathrm{~L}$ capacity. The tanks were supplied with filtered seawater at a flow rate of $4 \mathrm{~L} / \mathrm{min}$ and aeration to maintain enough dissolved oxygen. Triplicate groups of fish were fed one of the diets to apparent satiation twice a day (08:00 and 18:00 h) for $15 \mathrm{wk}$. Uneaten food was siphoned out after $30 \mathrm{~min}$ of feeding and weighed to determine feed intake. Growth of fish was measured at every 3 weeks. Feeding was stopped $24 \mathrm{~h}$ prior to weighing or blood sampling to minimize stress on the fish.

\section{Sample collection and analyses}

At the end of the feeding trial, all the fish in each tank were weighed, counted and their total and fork length were measured for calculation of growth parameters and survival. Also, three fish per tank (nine fish per dietary treatment) were randomly captured, anaesthetized with 2phenoxyethanol solution (200 mg/L) and blood samples were taken from the caudal vein with heparinized syringes to determine respiratory burst activity and total immunoglobin level. Additionally, another set of blood samples were taken from the caudal vein of three fish from each tank using nonheparinized syringes, allowed to clot at room temperature for $30 \mathrm{~min}$, and the serum was separated by centrifugation for $10 \mathrm{~min}$ at $5,000 \times \mathrm{g}$ and stored at $-70^{\circ} \mathrm{C}$ for analysis of the other innate immune response parameters including lysozyme, myeloperoxidase (MPO), superoxide dismutase (SOD) and antiprotease activities.

The oxidative radical production by phagocytes during respiratory burst was measured using the NBT (nitro-bluetetrazolium) assay described by Anderson and Siwicki (1995). Briefly, blood and NBT (0.2\%) (Sigma, St. Louis, MO, USA) were mixed in equal proportion (1:1) and incubated for $30 \mathrm{~min}$ at room temperature. Then, $50 \mu \mathrm{L}$ was removed and dispensed into glass tubes. One $\mathrm{mL}$ of 
dimethylformamide (Sigma) was added and centrifuged at $2,000 \times g$ for $5 \mathrm{~min}$. Finally, the optical density of the supernatant was measured at $540 \mathrm{~nm}$ using a spectrophotometer (Genesys 10UV, Rochester, NY, USA). Dimethylformamide was used as the blank.

A turbidometric assay was used to determine serum lysozyme activity using the method described by Hultmark (1980) with slight modifications. Briefly, Micrococcus lysodeikticus $(0.75 \mathrm{mg} / \mathrm{mL})$ was suspended in sodium phosphate buffer ( $\mathrm{pH} 6.4,0.1 \mathrm{M}), 200 \mu \mathrm{L}$ of suspension was placed in each well of a 96-well plate, and $20 \mu \mathrm{L}$ of serum was added. The reduction in absorbance of samples was determined at $570 \mathrm{~nm}$ in a microplate reader (UVM 340, Biochrom, Cambridge, UK) after a room temperature incubation for 0 and $30 \mathrm{~min}$. Hen egg white lysozyme (Sigma) was used for the standard curve. Values are expressed as $\mu \mathrm{g} / \mathrm{mL}$.

Serum MPO activity was measured according to Quade and Roth (1997). Briefly, $20 \mu \mathrm{L}$ of serum was diluted with Hanks Balanced Salt Solution (HBSS, Sigma) without $\mathrm{Ca}^{2+}$ and $\mathrm{Mg}^{2+}$ in 96-well plates. Then, $35 \mu \mathrm{L}$ of 3,3',5,5'tetramethylbenzidine hydrochloride (TMB, $20 \mathrm{mM}$ ) (Sigma) and $\mathrm{H}_{2} \mathrm{O}_{2}(5 \mathrm{mM})$ were added. The color change reaction was stopped after 2 min by adding $35 \mu \mathrm{L}$ of $4 \mathrm{M}$ sulfuric acid. Finally, optical density was read at $450 \mathrm{~nm}$ in a microplate reader.

SOD activity was measured by the percentage reaction inhibition rate of enzyme with water soluble tetrazolium dye substrate and xanthine oxidase using a SOD Assay Kit (Sigma, 19160) according to the manufacturer's instructions. Each endpoint assay was monitored by absorbance at 450 $\mathrm{nm}$ (the absorbance wavelength for the colored product of the WST-1 reaction with superoxide) after $20 \mathrm{~min}$ of reaction time at $37^{\circ} \mathrm{C}$. Percent inhibition was normalized by mg protein and presented as SOD activity units.

Plasma total immunoglobulin (Ig) level was determined according to the method described by Siwicki and Anderson (1993). Briefly, plasma total protein content was measured using a micro protein determination method (C-690; Sigma), prior to and after precipitating down the immunoglobulin molecules, using a $12 \%$ solution of polyethylene glycol (Sigma). The difference in protein content represents the Ig content.

Serum antiprotease activity was measured according to the method described by Ellis (1990) with slight modifications (Magnadóttir et al., 1999). Briefly, $20 \mu \mathrm{L}$ of serum was incubated with $20 \mu \mathrm{L}$ of standard trypsin solution (Type II-S, from porcine pancreas, $5 \mathrm{mg} / \mathrm{mL}$, Sigma) for $10 \mathrm{~min}$ at $22^{\circ} \mathrm{C}$. Then, $200 \mu \mathrm{L}$ of phosphate buffer (0.1 M, pH 7.0) and $250 \mu \mathrm{L}$ azocasein (2\%) (Sigma) were added and incubated for $1 \mathrm{~h}$ at $22^{\circ} \mathrm{C}$. Five hundred microliters of $10 \%$ trichloro acetic acid was added and further incubated for $30 \mathrm{~min}$ at $22^{\circ} \mathrm{C}$. The mixture was centrifuged at $6,000 \times g$ for $5 \mathrm{~min}$, and $100 \mu \mathrm{L}$ of the supernatant was transferred to the wells of a 96 well flat bottomed microplate containing $100 \mu \mathrm{L}$ of $1 \mathrm{~N} \mathrm{NaOH}$. Optical density was read at $430 \mathrm{~nm}$. Buffer replaced the serum for the $100 \%$ positive control, and buffer replaced both serum and trypsin for the negative control. The trypsin inhibition percentage was calculated using the following equation:

\section{Trypsin inhibition $(\%)=\left(\mathrm{A}_{1}-\mathrm{A}_{2} / \mathrm{A}_{1}\right) \times 100$}

where $A_{1}=$ control trypsin activity (without serum); $A_{2}$ $=$ trypsin activity remaining after adding serum.

Also, at the end of the experiment three fish per tank were randomly selected in the early morning, killed with an overdose of 2-phenoxyethanol and dissected for measurement of hepatosomatic index (HSI) and relative length of the gut (RLG). For analysis of goblet cells, the intestine samples were fixed in Bouin's solution, dehydrated in a graded series of ethanol, embedded in paraffin and then cut into $5 \mu \mathrm{m}$ cross-sections. The slides were stained with Alcian blue (AB) at $\mathrm{pH} 2.5$ and periodic acid-Schiff (PAS) for observation of the mucus- secreting goblet cells. The slides were observed using a light microscope (Carl Zeiss, HBO 50) with image scope 2.3 (Image Line, Inc) software. Photographs were taken using a canon digital photomicrographic system.

\section{Digestibility test}

To examine the effect of Barodon on feed digestibility, the commercial diet used in the feeding trial was ground, supplemented with $0.1 \%$ and $0.2 \%$ Barodon and after addition of $1.0 \%$ chromic oxide $\left(\mathrm{Cr}_{2} \mathrm{O}_{3}\right)$ as an inert indicator (Sigma-Aldrich, St. Louis, USA) and 30\% double distilled water, it was then extruded through a meat chopper machine (SMC-12, Kuposlice, Busan, Korea) set at $3 \mathrm{~mm}$ in diameter. The pellets were dried with electric fans at room temperature and maintained at $-20^{\circ} \mathrm{C}$ until use. Twenty fish $(122 \mathrm{~g})$ were distributed into each $300 \mathrm{~L}$ capacity Guelph system (fecal collection system) tanks. The tanks were supplied with cartridge-filtered seawater at a flow rate of 1 $\mathrm{L} / \mathrm{min}$ and aeration. Duplicate groups of fish were hand-fed one of the test diets to apparent satiation once daily at 18:00 h. One hour after feeding, the rearing tanks were brushed out to remove uneaten feed and fecal residues. On the next day, feces were collected from the fecal collection columns. The collected feces in the tube was separated from supernatant water using a disposable paper filter and stored at $-40^{\circ} \mathrm{C}$. Then the fecal samples were freeze-dried for $24 \mathrm{~h}$ and stored at $-20^{\circ} \mathrm{C}$ until analysis.

Chromium oxide content of diet and feces samples was 
analyzed according to the method described by Divakaran et al. (2002) at the Fish Feed and Nutrition Laboratory, Jeju National University, Jeju, Korea. Briefly, a known wt (5 to $10 \mathrm{mg}$ ) of ash samples of either diet or feces containing chromium oxide was placed in glass test tubes. Four milliliter of perchloric reagent was added along the sides of the test tube to wash down any adhering ash. Perchloric reagent was prepared as follows: two hundred milliliter of concentrated nitric acid was added to $100 \mathrm{~mL}$ of distilled water cooled down then $200 \mathrm{~mL}$ perchloric acid (70\%) was added. The test tubes were set in a heating block and heated at $300^{\circ} \mathrm{C}$ for $20 \mathrm{~min}$, for oxidation of chromium oxide to monochromate $\left(\mathrm{CrO}_{4}{ }^{2-}\right)$. Then the tubes were cooled down to room temperature and their contents were quantitatively transferred and made up to $25 \mathrm{~mL}$ in a volumetric flask by rinsing repeatedly with distilled water. The absorbance of samples was read at $350 \mathrm{~nm}$ using a spectrophotometer (Beckman DU-730, USA). A known wt (2 to $4 \mathrm{mg}$ ) of chromium oxide was similarly treated and used as standard.

The apparent digestibility coefficients (ADC) for DM and protein of the experimental diets were calculated through the following formulas:

$$
\begin{aligned}
& \text { ADC of DM }(\%) \\
& =100-100 \times\left(\% \mathrm{Cr}_{2} \mathrm{O}_{3} \text { in diet } / \% \mathrm{Cr}_{2} \mathrm{O}_{3} \text { in feces }\right) \\
& \quad \times(\% \mathrm{DM} \text { in feces } / \% \mathrm{DM} \text { in diet })
\end{aligned}
$$

$$
\begin{aligned}
& \text { ADC of protein }(\%) \\
& =100-100 \times\left(\% \mathrm{Cr}_{2} \mathrm{O}_{3} \text { in diet } / \% \mathrm{Cr}_{2} \mathrm{O}_{3} \text { in feces }\right) \\
& \quad \times(\% \text { protein in feces } / \% \text { protein in diet })
\end{aligned}
$$

\section{Statistical analysis}

All the diets were assigned by a completely randomized design. Data were analyzed using linear and quadratic orthogonal polynomial contrasts in SPSS version 19 (SPSS Inc., Chicago, IL, USA). Statistical significance was determined at $5 \%(\mathrm{p} \leq 0.05)$. Percentage data were arcsine transformed before analysis.

\section{RESULTS}

The results of fish growth performance fed the experimental diets are presented in Table 2. Inclusion of Barodon in the diets resulted in a numerical increase of fish growth; but the differences were not significant ( $p>0.05)$. However, the use of Barodon significantly improved (linear and quadratic, $\mathrm{p}<0.05$ ) feed utilization efficiency where a significantly lower feed conversion ratio and a higher protein efficiency ratio were found in Barodon treated groups. Also, significantly higher survival rates $(p<0.05)$ were obtained in fish offered Barodon containing diets.

Dietary supplementation of Barodon resulted in the significant increase of hepatosomatic index and intestine length (linear and quadratic, $\mathrm{p}<0.05$ ) (Table 2). The number of goblet cells was increased linearly and quadratically ( $\mathrm{p}<$ 0.05 ) by Barodon supplementation (Table 2 and Figure 1).

Apparent digestibility coefficients for DM and protein of the experimental diets are provided in Table 3 . Significantly higher (Quadratic, $\mathrm{p}<0.05$ ) ADC of DM was found in Barodon fed fish and ADC of protein increased numerically by Barodon supplementation.

Significantly higher lysozyme (Quadratic, $\mathrm{p}<0.05)$ and MPO (linear, $\mathrm{p}<0.05$ ) activities were found in Barodon fed

\begin{tabular}{|c|c|c|c|c|c|c|}
\hline \multirow{2}{*}{ Items } & \multicolumn{3}{|c|}{ Barodon concentration (\%) } & \multirow{2}{*}{ SEM } & \multicolumn{2}{|c|}{$\mathrm{p}$ value } \\
\hline & Control & 0.1 & 0.2 & & Linear & Quadratic \\
\hline $\mathrm{FBW}^{2}$ & 502 & 541 & 550 & 26.48 & 0.59 & 0.15 \\
\hline $\mathrm{WG}^{3}$ & 246 & 271 & 275 & 19.35 & 0.10 & 0.21 \\
\hline $\mathrm{SGR}^{4}$ & 0.91 & 1.01 & 1.02 & 0.08 & 0.11 & 0.21 \\
\hline $\mathrm{FCR}^{5}$ & 1.25 & 1.01 & 0.91 & 0.06 & $<0.05$ & $<0.05$ \\
\hline $\mathrm{PER}^{6}$ & 1.38 & 1.72 & 1.91 & 0.11 & $<0.05$ & $<0.05$ \\
\hline Survival (\%) & 70.7 & 92.0 & 96.0 & 5.81 & $<0.05$ & $<0.05$ \\
\hline $\mathrm{CF}^{7}$ & 1.13 & 1.14 & 1.09 & 0.07 & 0.45 & 0.63 \\
\hline $\mathrm{HSI}^{8}$ & 1.72 & 2.16 & 2.35 & 0.16 & $<0.05$ & $<0.05$ \\
\hline $\mathrm{RLG}^{9}$ & 63.4 & 82.8 & 81.4 & 6.28 & $<0.05$ & $<0.05$ \\
\hline Goblet cells number & 1,456 & 1,834 & 2,342 & 257 & $<0.05$ & $<0.05$ \\
\hline
\end{tabular}
fish (Table 4). Also, SOD activity significantly increased (linear and quadratic, $\mathrm{p}<0.05$ ) in fish offered Barodon. However, NBT and antiprotease activities as well as Ig level were not significantly influenced (Table 4).

Table 2. Growth performance and organosomatic indices of olive flounder (BW, $145 \mathrm{~g})$ fed the experimental diets for $15 \mathrm{wk}^{1}$

${ }^{1}$ Values are means of triplicate groups. ${ }^{2}$ Final BW $(\mathrm{g})$.

${ }^{3} \mathrm{Wt}$ gain $(\%)=[($ Final mean $\mathrm{BW}-$ initial mean $\mathrm{BW}) /$ initial mean $\mathrm{BW} \times 100]$.

${ }^{4}$ Specific growth rate $(\%)=[(\ln$ mean final BW-ln mean initial $\mathrm{BW}) / \mathrm{d}] \times 100$.

${ }^{5}$ Feed conversion ratio $=$ Dry feed fed/wet wt gain. ${ }^{6}$ Protein efficiency ratio $=$ Wet wt gain/total protein given.

${ }^{7}$ Condition factor $=$ Body wt/fork length ${ }^{3} \cdot{ }^{8}$ Hepatosomatic index $=($ Liver wt/body wt $) \times 100$.

${ }^{9}$ Relative length of the gut $=($ Intestine length/fish length $) \times 100$. 

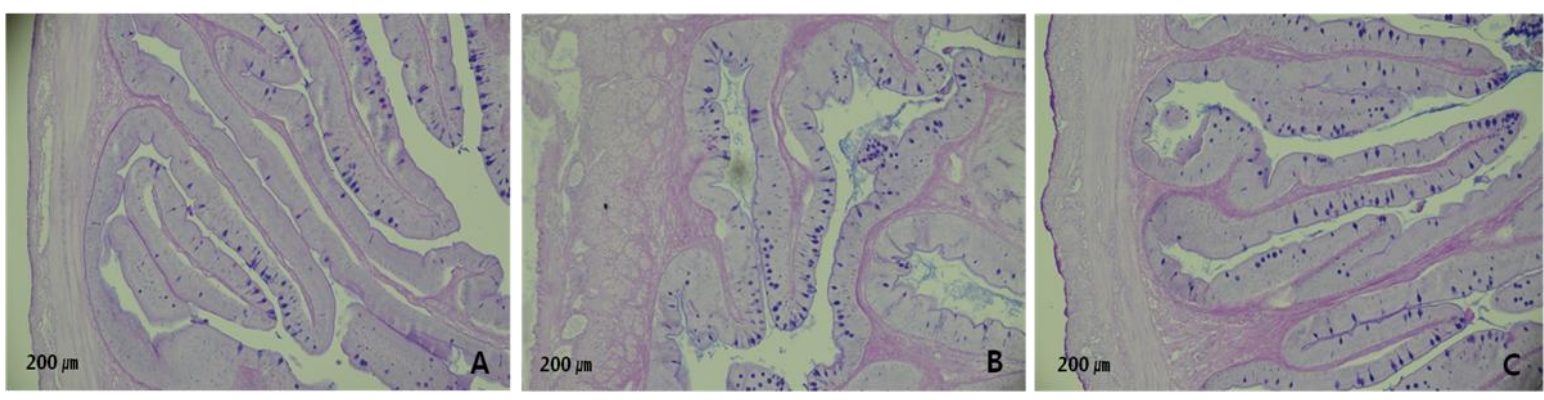

Figure 1. Microphotographs of mucus-secreting goblet cells in anterior intestine of olive flounder fed the experimental diets for 15 wk.

Table 3. Apparent digestibility coefficients (ADC, \%) for DM and $\mathrm{CP}$ of the experimental diets for olive flounder ${ }^{1}$

\begin{tabular}{lcccccc}
\hline & \multicolumn{3}{c}{ Barodon } & & \multicolumn{2}{c}{$\mathrm{p}$ value } \\
\cline { 2 - 4 } Items & \multicolumn{2}{c}{ concentration (\%) } & SEM & \multicolumn{2}{c}{} \\
\cline { 2 - 3 } \cline { 7 - 7 } & Control & 0.1 & 0.2 & & Linear & Quadratic \\
\hline $\mathrm{DM}$ & 77.2 & 79.8 & 76.7 & 0.74 & 0.71 & $<0.05$ \\
$\mathrm{CP}$ & 86.9 & 89.8 & 88.4 & 1.18 & 0.29 & 0.07 \\
\hline
\end{tabular}

${ }^{1}$ Values are means of triplicate groups.

\section{DISCUSSION}

Results of this study showed the slight improvement of fish growth performance and significant increase of feed utilization efficiency by dietary supplementation of Barodon. There is limited available information on beneficial effects of Barodon in fish species. Barodon is a mixture of sodium silicate and certain metal salts in an alkaline solution, of which sodium silicate represents $60 \%$ of the total amount. The exact underlying mechanism of action of Barodon is unknown. However, it has been suggested that sodium silicate, the main mineral ingredient, decomposes quantitatively into bioavailable ortho-silicic acid in the acidic gastric juice and is absorbed in the body (Jurkić et al., 2013). Carlisle (1969, 1970) reported that silicon is uniquely localized in active growth areas in bones of animals. It has been shown that silicon plays essential roles in growth and skeletal development in chicks. A significant reduction in skeletal development was observed when the chicks were deprived of silicon (Carlisle, 1970). Such biological effects of silicon have been attributed to its interrelationships with other elements in the body including molybdenum, aluminium and calcium (Smith, 1993; Exley et al., 2006).

Activity of digestive enzymes is greatly influenced by $\mathrm{pH}$. Indeed, the digestion process is performed in a neutralalkaline condition (Munilla-Morán and Saborido-Rey, 1996a). Munilla-Morán and Saborido-Rey (1996 a,b) reported that the optimum $\mathrm{pH}$ range for the action of digestive protease and amylase enzymes are 9.5-10 and 7.07.5, respectively, in gilthead seabream (Sparus aurata). Also, Sabapathy and Teo (1995) found that the optimal chymotrypsin activity of rabbitfish occurs at a $\mathrm{pH}$ range from 7.5 to 8.0. The improvement of fish feed utilization in the present study can be at least partially due to the enhancement in digestive enzymes activity, as Barodon is an alkaline solution and can aid in better enzymatic digestion.

The results of digestibility test in this study provide more evidence for positive effects of Barodon supplementation on fish feed utilization. The results showed a significant increase in digestibility of DM by inclusion of $0.1 \%$ Barodon and slight improvement of dietary protein digestibility in Barodon treated groups. Such enhancement in feed digestibility can be probably due to the facilitated digestive enzymes activity, particularly proteolytic enzymes.

On the other hand, Barodon serves as a supplemental source of minerals. Minerals are used for maintenance of skeletal formation and colloidal system, acid-base equilibrium and are used for biologically important compounds like the hormones and enzymes (Watanabe et

Table 4. Non-specific immune responses of olive flounder fed the experimental diets for $15 \mathrm{wk}^{1}$

\begin{tabular}{|c|c|c|c|c|c|c|}
\hline \multirow{2}{*}{ Items } & \multicolumn{3}{|c|}{ Barodon concentration (\%) } & \multirow{2}{*}{ SEM } & \multicolumn{2}{|c|}{$\mathrm{p}$ value } \\
\hline & Control & 0.1 & 0.2 & & Linear & Quadratic \\
\hline $\mathrm{NBT}^{2}$ & 0.84 & 0.96 & 0.88 & 0.12 & 0.71 & 0.47 \\
\hline $\mathrm{MPO}^{3}$ & 1.29 & 1.58 & 1.88 & 0.23 & $<0.05$ & 0.06 \\
\hline Lysozyme $^{4}$ & 17.26 & 31.38 & 25.71 & 5.00 & 0.18 & $<0.05$ \\
\hline $\operatorname{Ig}^{5}$ & 18.74 & 20.64 & 18.24 & 1.53 & 0.75 & 0.21 \\
\hline Antiprotease $^{6}$ & 16.10 & 17.37 & 20.52 & 2.64 & 0.07 & 0.19 \\
\hline $\mathrm{SOD}^{7}$ & 69.92 & 74.59 & 82.22 & 3.78 & $<0.05$ & $<0.05$ \\
\hline
\end{tabular}

${ }^{1}$ Values are means of triplicate groups. ${ }^{2}$ Nitro blue tetrazolium activity (absorbance). ${ }^{3}$ Myeloperoxidase activity (absorbance).

${ }^{4}$ Lysozyme activity $(\mu \mathrm{g} / \mathrm{mL}) .{ }^{5}$ Total immunoglobulin $(\mathrm{mg} / \mathrm{mL}) .{ }^{6}$ Antiprotease activity (\% inhibition). ${ }^{7}$ Superoxide dismutase activity $(\%$ inhibition). 
al., 1997). It has been shown that deficiency of minerals results in biochemical, structural and functional pathologies.

Digestive tissues are flexible and show morphological changes in response to dietary manipulations (Starck, 1999). It has been demonstrated that fasting, increases in feed intake and changes in diet composition affect gut morphological parameters (Naya et al., 2007; Olsson et al., 2007). The length of gut is one of the important factors in nutrient absorption (Hofer and Schiemer, 1981). Ricklefs (1996) and Lavin et al. (2008) reported that the changes in intestine length influence the digestion and assimilation of nutrients. In the current study, significant increases were found in intestine length in Barodon fed groups. Such increase in the intestine length can positively affect nutrient digestion and absorption by enhancement of surface area, volume, villus area and other involving features.

Histological studies provide an approach for understanding pathological changes related to dietary manipulations (Gargiulo et al., 1998). In the present study, a higher number of mucus-secreting goblet cells was found in the anterior intestine of Barodon treated groups. Goblet cells are distributed throughout the gastrointestinal tract and provide protection against damage from chemical substances and digestive enzymes by secreting mucus (Allen et al., 1986). Also, they are responsible for the production of high molecular wt glycoprotein compounds known as mucins which is the major component of the intestinal mucus layer (Kim and Khan, 2013). Mucins are the key protective component of mucus. Murray et al. (1996) reported that the increment of goblet cells number results in higher mucosal membrane protection. Moreover, Osman and Caceci (1991) and Domeneghini et al. (2005) suggested that goblet cells positively affect the absorption of digestible substances. There is now abundant evidence that the mucins are probably the first molecules that interact with pathogens and provide protection by inhibiting binding to other glycoproteins and neutralizing the pathogens. The enhancement of goblet cells number in the current study can result in improvements in feed utilization and absorption as well as higher protection against invading pathogens.

Immunostimulatory activity of Barodon has been earlier reported in horses (Koo et al., 2006) and pigs (Yoo et al., 2001). Its immunomodulatory activity has been reported in pigs to be through the proliferation and activation of porcine immune cells, particularly $\mathrm{CD} 4^{+} \mathrm{CD} 8^{+}$doublepositive T lymphocytes (Yoo et al., 2001, 2002). Jurkić et al. (2013) suggested that ortho-silicic acid is responsible for the pharmacological effects of Barodon. The exact mode of action of Barodon is not clear, but it has been assumed that its mineral components affect the membrane-associated lymphoid tissues (Koo et al., 2006). Innate immune response of olive flounder was upregulated by Barodon in this study, and significantly higher lysozyme, MPO and SOD activities were found by Barodon supplementation. However, the other tested immune parameters were not significantly influenced. The innate immune system of fish comprises several humoral and cellular factors that may differentially respond to the offered immunostimulant (Secombes, 1996); accordingly different results were obtained for the examined immune parameters in the current study.

In conclusion, the results showed the beneficial effects of dietary supplementation of Barodon on feed utilization, gut histology and innate immunity of olive flounder. However, further studies are necessary for establishment of the optimum Barodon level in diets for olive flounder.

\section{ACKNOWLEDGEMENTS}

This study was supported by Cargill Agri Purina, Inc. and Barodon-S.F. Corp. Salaries were partly supported by the National Research Foundation of Korea (NRF) grant funded by the Korea government (MEST) (No. 20110015925).

\section{REFERENCES}

Allen, A., D. A. Hutton, A. J. Leonard, J. P. Pearson, and L. A. Sellers. 1986. The role of mucus in the protection of the gastroduodenal mucosa. Scand. J. Gastroenterol. 21:71-78.

Anderson, D. P. and A. K. Siwicki. 1995. Basic haematology and serology for fish health programs. In: Diseases in Asian aquaculture II (Ed. M. Shariff, J. R. Arthur, and R. P. Subasinghe). Fish health section, Asian Fisheries Society, Manila, pp. 185-202.

Ardo, L., G. Yin, P. Xu, L. Varadi, G. Szigeti, Z. Jeney, and G. Jeney. 2008. Chinese herbs Astragalus membranaceus and Lonicera japonica and boron enhance the non-specific immune response of Nile tilapia Oreochromis niloticus and resistance against Aeromonas hydrophila. Aquaculture 275:26-33.

Carlisle, E. M. 1969. Silicon localization and calcification in developing bone. Fed. Proc. 28: 374.

Carlisle, E. M. 1970. A relationship between silicon and calcium in bone formation. Fed. Proc. 29:565.

Carnevali, O., M. C. Zamponi, R. Sulpizio, A. Rollo, M. Nardi, C. Orpianesi, S. Silvi, M. Caggiano, A. M. Polzonetti, and A. Cresci. 2004. Administration of probiotic strain to improve sea bream wellness during development. Aquacult. Int. 12:377-386.

Castaño-Sánchez, C., K. Fuji, A. Ozaki, O. Hasegawa, T. Sakamoto, K. Morishima, I. Nakayama, A. Fujiwara, T. Masaoka, H. Okamoto, K. Hayashida, M. Tagami, J. Kawai, Y. Hayashizaki, and N. Okamoto. 2010. A second generation genetic linkage map of Japanese flounder (Paralichthys olivaceus). BMC Genomics 11:554.

Divakaran, S., G. O. Leonard, and P. E. Ian. 2002. Note on the methods for determination of chromic oxide in shrimp feeds. J. Agric. Food. Chem. 50:464-467. 
Divyagnaneswari, M., D. Christybapita, and R. D. Michael. 2007. Enhancement of nonspecific immunity and disease resistance in Oreochromis mossambicus by Solanum trilobatum leaf fractions. Fish Shell. Immunol. 23:249-259.

Domeneghini, C., S. Arrighi, G. Radaelli, G. Bosi, and A. Veggetti. 2005. Histochemical analysis of glycoconjugate secretion in the alimentary canal of Anguilla anguilla L. Acta Histochemica 106:477-487.

Ellis, A. E. 1990. Serum antiprotease in fish. In: Techniques in Fish Immunology (Ed. J. S. Stolen, T. C. Fletcher, D. P. Anderson, B. S. Roberson, and W. B. Van Muiswinker). SOS Publication, Fair Haven, New Jersey, USA, pp. 95-99.

Exley, C., O. Korchazhkina, D. Job, S. Strekopytov, A. Polwartand, and P. Crome. 2006. Noninvasive therapy to reduce the body burden of aluminium in Alzheimer's disease. J. Alzheimers Dis. 10:17-24.

FAO, 2010. The State of World Fisheries and Aquaculture 2010. Food and Agriculture Organization of the United Nations, Rome.

Gannam, A. L. and R. M. Schrock. 2001. Immunostimulants in fish diets. In: Nutrition and Fish Health. Food Products Press (Ed. C. Lim and C. D. Webster). Food Products Press, New York, USA, pp. 235-266.

Gargiulo, A. M., P. Ceccarelli, C. Dall Aglio, and V. Pedini. 1998. Histology and ultrasturucture of the gut of the tilapia (Tilapia spp.), a hybrid teleost. Anat. Histol. Embryol. 27:89-94.

Hofer, R. and F. Schiemer. 1981. Proteolytic activity in the digestive tract of several species of fish with different feeding habits. Oecologia 48:342-345.

Hultmark, D. 1980. Insert immunity: purification and properties of three inducible bactericidal proteins from hemolymph of immunized pupae of Hyalophora cecropia. Eur. J. Biochem. 106:7-16.

Jurkić, L. M., L. Cepanec, S. K. Pavelić, and K. Pavelić. 2013. Biological and therapeutic effects of ortho-silicic acid and some ortho-silicic acid releasing compounds: new perspectives for therapy. Nutr. Metab. 10:2.

Kang, J. H., W. J. Kim, and W. J. Lee. 2008. Genetic linkage map of olive flounder, paralichthys olivaceus. Int. J. Biol. Sci. 4: 143-149.

Kim, J. J. and W. I. Khan. 2013. Goblet cells and mucins: Role in innate defense in enteric infections. Pathogens 2:55-70.

Koo, H. C., S. H. Ryu, H. J. Ahn, W. K. Jung, Y. K. Park, N. H. Kwon, S. H. Kim, J. M. Kim, B. W. Yoo, and S. I. Choi. 2006. Iuunostimulatory effects of the anionic alkali mineral complex Barodon on Equine lymphocyte. Clin. Vaccine Immunol. 13: 1255-1266.

Kumari, J. and P. K. Sahoo. 2006. Dietary levamisole modulates the immune response and disease resistance of Asian catfish Clarias batrachus (Linnaeus). Aquacult. Res. 37:500-509.

Lauzon, H. L., B. Margeirsson, K. Sveinsdóttir, M. Gudjónsdóttir, M. G. Karlsdóttir, and E. Martinsdóttir. 2010. Overview on fish quality research: impact of fish handling, processing, storage and logistics on fish quality deterioration. Skýrsla Matís 39-10, $70 \mathrm{p}$.

Lavin, S. R., W. H. Karasov, A. R. Ives, K. M. Middleton, and T. Garland Jr. 2008. Morphometrics of the avian small intestine, compared with non-flying mammals: a phylogenetic approach. Physiol. Biochem. Zool. 81:526-550.
Magnadóttir, B., H. Jonsdottir, S. Helgason, B. Bjornsson, T. Jørgensen, and L. Pilströ. 1999. Humoral immune parameters in Atlantic cod (Gadus morhua L) I: the effects of environmental temperature. Comp. Biochem. Physiol. Part B. Biochem. Mol. Biol. 122:173-180.

Munilla-Morán, R. and F. Saborido-Rey. 1996a. Digestive enzymes in marine species. I. Proteinase activities in gut from redfish (Sebastes mentella), seabream (Sparus aurata) and turbot (Scophthalmus maximus). Comp. Biochem. Physiol. Part B. Biochem. Mol. Biol. 113:395-402.

Munilla-Morán, R. and F. Saborido-Rey. 1996b. Digestive enzymes in marine species. II. Amylase activities in gut from seabream (Sparus aurata), turbot (Scophthalmus maximus) and redfish (Sebastes mentella). Comp. Biochem. Physiol. Part B. Biochem. Mol. Biol. 113:827-834.

Murray, H. M., G. M. Wright, and G. P. Goff. 1996. A comparative histological and histochemical study of the post gastric alimentary canal from three species of pleuronectids, the Atlantic halibut, the yellowtail flounder and the winter flounder. J. Fish Biol. 48:187-206.

Naya, D. E., W. H. Karasov, and F. Bozinovic. 2007. Phenotypic plasticity in laboratory mice and rats: Meta-analysis of current ideas on gut size flexibility. Evol. Ecol. Res. 9:1363-1374.

Olsson, J., M. Quevedo, C. Colson, and R. Svanback. 2007. Gut length plasticity in perch: into the bowels of resource polymorphisms. Biol. J. Linn. Soc. 90:517-523.

Osman, A. H. K. and T. Caceci. 1991. Histology of the stomach of Tilapia nilotica (Linnaeus, 1758) from the River Nile. J. Fish Biol. 38:211-223.

Park, B. K., Y. H. Park, and K. S. Seo. 2000. Relation between lymphocyte subpopulations of peripheral blood and immune responses of modified live hog cholera virus vaccine in pigs treated with an ionized alkali mineral complex. J. Vet. Sci. 1:49-52.

Quade, M. J. and J. A. Roth. 1997. A rapid, direct assay to measure degranulation of bovine neutrophil primary granules. Vet. Immunol. Immunopathol. 58:239-248.

Ricklefs, R. E. 1996. Morphometry of the digestive tracts of some passerine birds. The Condor 98:279-292.

Sabapathy, U. and L. H. Teo. 1995. Some properties of the intestinal proteases of the rabbitfish, Siganus canaliculatus (Park). Fish Physiol. Biochem. 14:215-221.

Sahu, S., B. K. Das, B. K. Mishra, J. Pradhan, and N. Sarangi. 2007. Effect of Allium sativum on the immunity and survival of Labeo rohita infected with Aeromonas hydrophila. J. Appl. Ichthyol. 23:80-86.

Sakai, M. 1999. Current research status of fish immunostimulants. Aquaculture 172:63-92.

Secombes, C. J. 1996. The nonspecific immune system: cellular defenses. In: The fish immune system. Organism, pathogen and environment (Ed. G. Iwama and T. Nakanishi). Academic press, San Diego, CA, USA, pp. 63-101.

Siwicki, A. K. and D. P. Anderson. 1993. Nonspecific defense mechanisms Assay in fish. In: II. Potential killing activity of neutrophils and macrophages, lysozyme activity in serum and organs and total immunoglobulin level in serum (Ed. A. K. Siwicki, D. P. Anderson, and J. Waluga). Fish Disease Diagnosis and Prevention Methods, Olsztyn, Poland, pp. 105112. 
Smith, B. L. 1993. Analysis of hair element levels by age, sex, race, and hair color. In: In trace elements in man and animals, TEMA 8 (Ed. M. Anke, D. Meissner and C. F. Mills). Kluwer, New York, USA, pp. 1091-1093.

Starck, J. M. 1999. Structural flexibility of the gastro-intestinal tract of vertebrates: implications for evolutionary morphology. Zool. Anz. 238:87-101.

Swain, P., S. Dash, P. K. Sahoo, P. Routray, S. K. Sahoo, S. D. Gupta, P. K. Meher, and N. Sarangi. 2007. Non-specific immune parameters of brood Indian major carp Labeo rohita and their seasonal variations. Fish Shell. Immunol. 22:38-43.

Watanabe, T., V. Kiron, and S. Satoh. 1997. Trace minerals in fish nutrition. Aquaculture 151:185-207.
Wu, G., C. Yuan, M. Shen, J. Tang, Y. Gong, D. Li, F. Sun, C. Huang, and X. Han. 2007. Immunological and biochemical parameters in carp Cyprinus carpio after Qompsell feed ingredients for long-term administration. Aquacult. Res. 38: 246-255.

Yoo, B. W., S. I. Choi, S. H. Kim, S. J. Yang, H. C. Koo, N. H. Kwon, S. H. Seo, B. K. Park, H. S. Yoo, and Y. H. Park. 2001. Immunostimulatory effects of anionic alkali mineral complex solution Barodon in porcine lymphocytes. J. Vet. Sci. 2:15-24.

Yoo, B. W., S. I. Choi, S. H. Kim, S. J. Yang, H. C. Koo, N. H. Kown, S. H. Seo, B. K. Park, H. S. Yoo, and Y. H. Park. 2002. Immunostimulatory effects of an anionic alkali mineral complex solution Barodon on porcine lymphocytes. J. Swine. Health. Prod. 10:265-270. 